\title{
The Impact of Ethical Concerns on Fashion Consumerism: Case- based Evidence
}

Lena Cavusoglu

Izmir University of Economics

Mourad Dakhli

Georgia State University

Follow this and additional works at: https://digitalcommons.uri.edu/mgdr

Part of the Fashion Business Commons, Marketing Commons, and the Other Business Commons

\section{Recommended Citation}

Cavusoglu, Lena and Dakhli, Mourad (2017) "The Impact of Ethical Concerns on Fashion Consumerism: Case-based Evidence," Markets, Globalization \& Development Review. Vol. 2: No. 1, Article 4.

DOI: 10.23860/MGDR-2017-02-01-04

Available at: https://digitalcommons.uri.edu/mgdr/vol2/iss1/4

This Article is brought to you for free and open access by DigitalCommons@URI. It has been accepted for inclusion in Markets, Globalization \& Development Review by an authorized editor of DigitalCommons@URI. For more information, please contact digitalcommons-group@uri.edu. 


\section{Markets, Globalization \& Development Review}
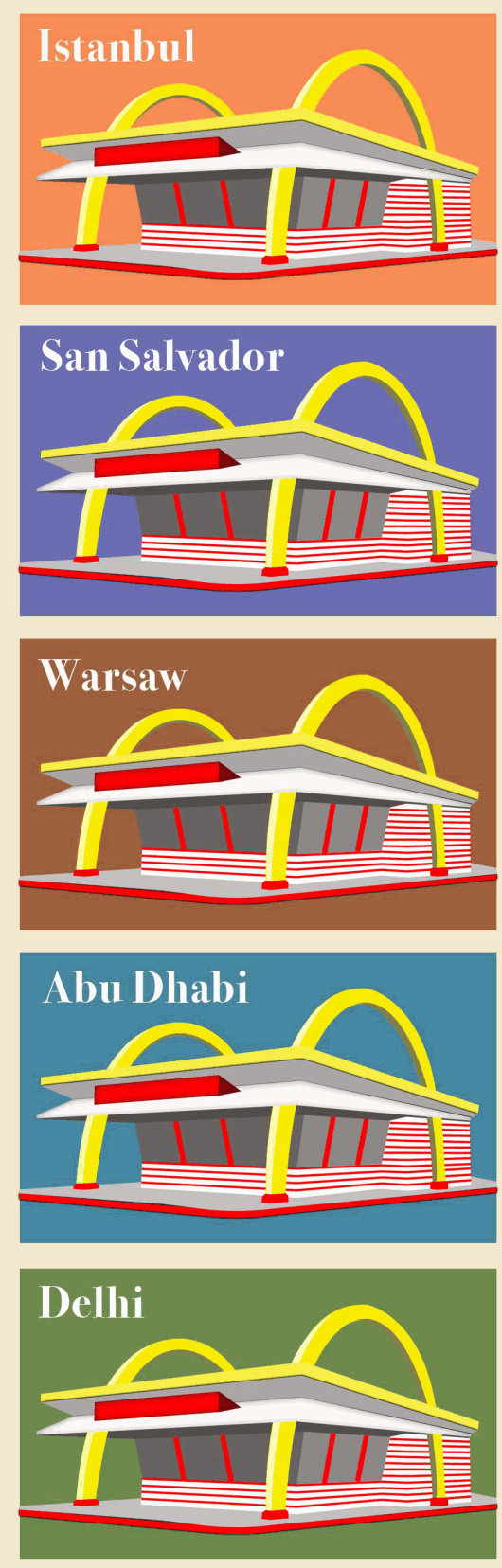
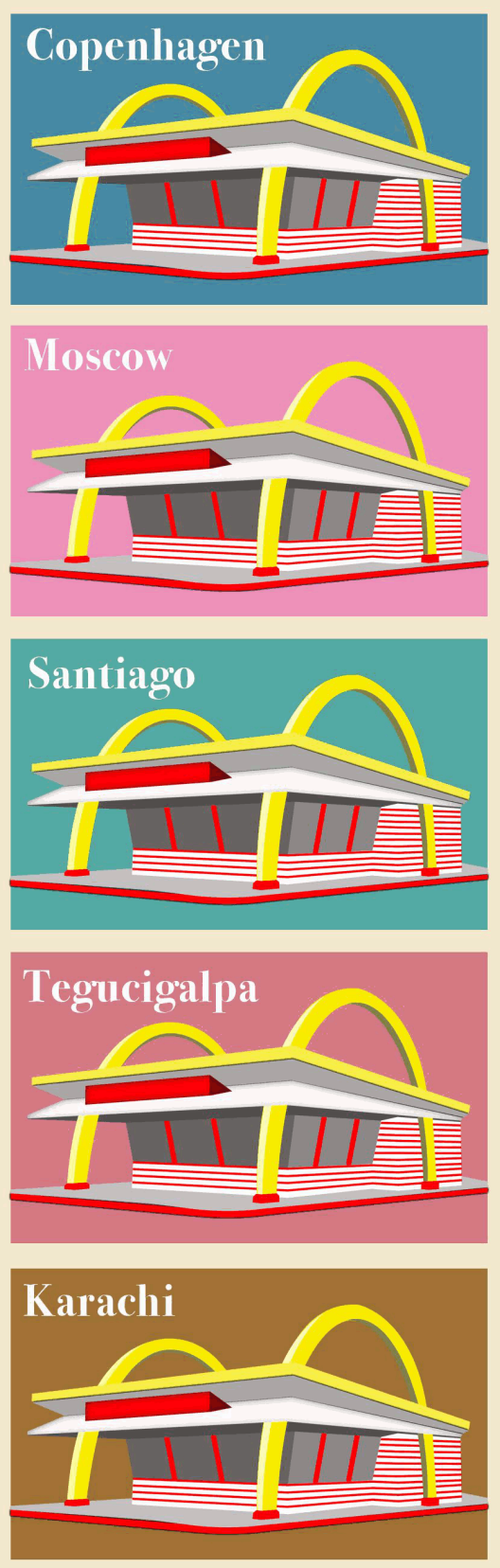
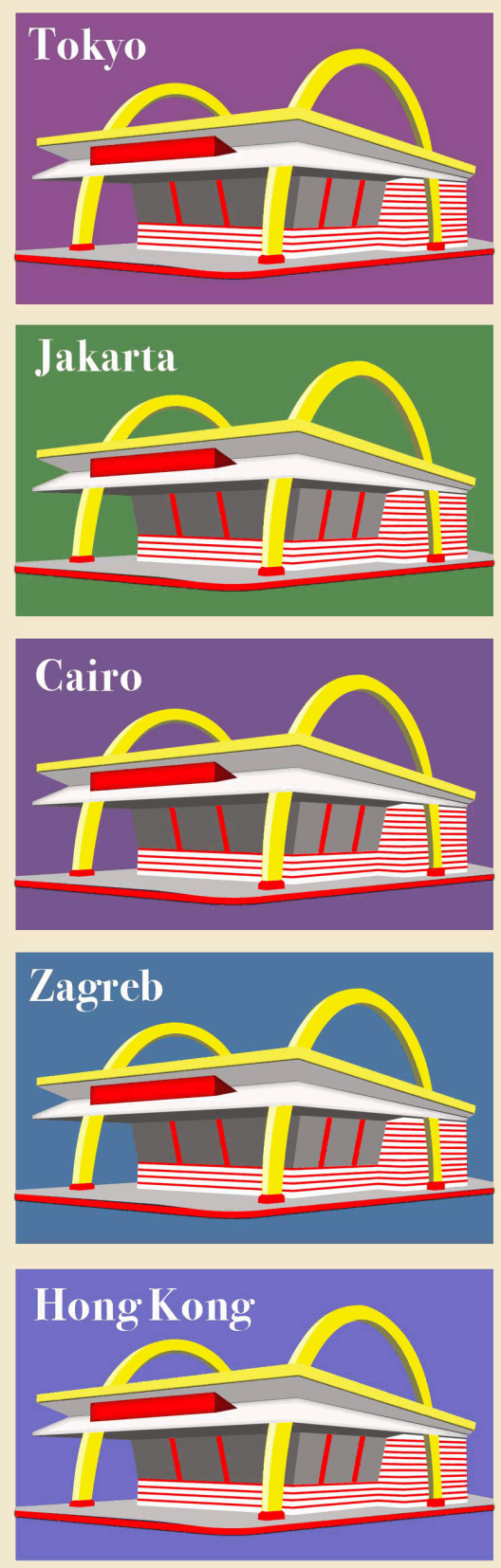

This article is available in Markets, Globalization \& Development Review: https://digitalcommons.uri.edu/mgdr/vol2/ 


\section{The Impact of Ethical Concerns on Fashion Consumerism: Case-based Evidence}

\section{Introduction}

In Paper I of this series (Cavusoglu and Dakhli 2016), we discussed the concept of ethical marketing in fashion, presented various ethical issues, and addressed the ethical concerns of consumers and other pressure groups. We argued that companies can be more successful in generating sales, creating a positive brand image, and improving their reputation and loyalty by making ethical and responsible practices a central element of their marketing and communications strategy. We reviewed the main ethical issues in fashion marketing, via a detailed literature review, with a focus on environmental and social well-being concerns, including sustainability, treatment of animals, use of body image, cultural and social values, fair labor practices, and charitable contributions. Based on previous research, our review showed that having a brand with an ethical stance enhances the firm's reputation and that this, in turn, reinforces the brand and its financial performance in the global marketplace.

As the next step of this study, in the second and concluding paper of the larger study, we address the ethical issues discussed in Paper I and show their impacts on brand reputation and corporate performance by presenting real-life anecdotes and high-profile cases from the fashion industry. We examine under what circumstances consumers react to instances of perceived unethical practices, presenting empirically based evidence. We conclude by addressing how ethical stance affects consumers' buying behavior.

\section{A Summary of the Literature Review}

In our previous paper (Cavusoglu and Dakhli 2016), we reviewed the related ethical fashion literature extensively and organized it under two major streams: environmental and social well-being concerns in the fashion industry.

Environmental concerns include any hazardous impact of the fashion industry on the world and eco-system, such as:

- Higher disposal rates due to large volumes of clothing production and, in turn, high levels of waste, which cause scarcity of natural resources.

- Lower quality clothing made of artificial fibers and harmful dyes that cause a significant negative environmental footprint. 
- Cruelty to animals, violation of animal rights, and harm to endangered species by using animal-based materials, such as wool, hides, fur, and leather, for clothing and accessories.

Social concerns include both the well-being of the people and communities behind the fashion industry and consumers, such as:

- Sweatshop labor or unfair labor practices, including underpayment of labor, violations of labor rights, and child labor.

- The sexual objectification of women's bodies in fashion communication, portrayed as an aesthetic object of desire for men.

- Unrealistic and misleading representation of the body through the use of photo-editing software, such as Photoshop, that establishes unattainable beauty standards.

- The depiction of an ultra-thin beauty ideal that has serious impacts on both the psychological and physical well-being of models, and women and teenagers in general.

- Controversial fashion ads that offend cultural, religious, and social norms.

\section{Methodology}

In this study of ethical concerns in the fashion industry, we employ a qualitative method based on existing cases. A qualitative, multiple case study design, more formally known as a "multiple embedded case study" (Yin 1994, p. 39), was used to examine the importance of the ethical marketing activities of fashion companies in terms of their financial performance and brand reputation. Stake (1978-2000, p. 20) noted:

Case studies will often be the preferred method of research because they may be epistemologically in harmony with the reader's experience and thus to that person a natural basis for generalization.

Therefore, employing multiple case studies as a methodology helped us to explore the contemporary phenomena within their natural context and provided a variety of evidence from different sources.

A total of 15 fashion campaigns that have shocked or offended consumers are compiled. With the help of today's technology, including corporate websites, social media, and online corporate social responsibility reports, such cases are easy to access and build. Table 1 provides a summary of the selected cases. Cases refers to advertising campaigns, supply chain practices, and corporate social responsibility activities of fashion firms that have media coverage. As suggested by 
Teddlie and Yu (2007), our sampling consists of individual and unique cases that are the focus of the investigation. The sample group of cases was purposively chosen to show variety. Low-price, mid-price, and highend segment fashion brands were taken into consideration to represent different consumer groups. In addition, organically formed data, such as consumer comments about the cases gathered from various websites (forums, news websites, and company websites), were included in the analysis.

\section{Table 1: Summary of the Selected Fashion Brand Real-Life Cases}

\begin{tabular}{|l|l|l|l|}
\hline No. & Brand & Campaign & Year \\
\hline 1 & DOVE & Real Beauty & 2004 \\
\hline 2 & ALDO Shoes & $\begin{array}{l}\text { Hear No Evil, See No Evil, } \\
\text { Speak No Evil }\end{array}$ & 2005 \\
\hline 3 & Girbaud Fashion House & Last Supper Campaign & 2005 \\
\hline 4 & American Eagle & AE Better World & 2007 \\
\hline 5 & Marks \& Spencer & Plan-A Campaign & 2007 \\
\hline 6 & Nolita & Isabella Caro & 2007 \\
\hline 7 & Dolce \& Gabbana & Spring/Summer Campaign & 2007 \\
\hline 8 & PETA & Tim Gunn's Expose & 2008 \\
\hline 9 & Ralph Lauren & Filippa Hamilton & 2009 \\
\hline 10 & Revolve Clothing & Allie Crandell & 2010 \\
\hline 11 & LK Bennett & Real Women & 2010 \\
\hline 12 & Calvin Klein & Lara Stone & 2010 \\
\hline 13 & Nike & $\begin{array}{l}\text { Sustainable Business } \\
\text { Performance Summary }\end{array}$ & 2012 \\
\hline 14 & Star Models & You Are Not a Sketch & 2013 \\
\hline 15 & EDUN & African Shower & 2013 \\
\hline
\end{tabular}

The real-life events that are used in this study are purposively sampled and, thus, non-probabilistic. Merriam (1998) suggested that a non-probability sample could be used as an efficient sampling method when the research concerns what is occurring, as does this study. A purposive sample allows the researcher to choose the elements (i.e., people, cases, and events) for the sample, based on his or her judgment, to answer the research question (Patton 1990).

Due to the triangulation of evidence, the multiple-case method provides a more rigorous and complete approach than does single-casestudy research (Bonoma 1985; Eisenhardt 1989). In addition, the cases served as a rich source of explanatory data to generalize how and why the phenomena occurred. As suggested by Stake (1994) and Remenyi et al. 
(1998), we aim to provide a structural representation with selected cases that match the purpose of the study. Therefore, we selected multiple cases that present real-life situations, and included the relevant visual data in the analysis, to increase the explanatory power and generalizability of the data collection process (Miles and Huberman 1994, p. 172). We accomplished this through replication rather than through sampling logic, as suggested by Zainal (2007).

Because we used purposive sampling in this study, researcher bias may be a concern. The previous study showed, however, that, when the aim of the research is "understanding, extension of experience, and an increase in the conviction in that which is known," as in this study, rather than "providing explanation, propositional knowledge, and law," the bias disappears (Stake 1978-2000, p. 21). In this study, our aim is not to discover external reality but, rather, to shed light on the phenomena through explanation and thick descriptions as well as provision of integrated interpretations of situations and contexts.

\section{Findings}

In this section, we present selective cases from the fashion industry that illustrate ethical issues well, and conclude by surmising how ethical issues influence consumers' buying behavior. To be consistent with the literature review, we display the cases under two categories: environmental and social well-being.

\section{Fashion Cases Related to Environmental Well-being}

Research has shown that environmentally friendly or green practices of fashion companies gain support from consumers (Kent 2007-2008). For instance, the Nike Sustainable Business Performance Summary (20122013) shows that the amount of energy used in a value chain fell $5 \%$ and that their greenhouse gas emissions fell $2.8 \%$ in 2013 from their levels in 2011 , while experiencing a revenue growth of $26 \%$ over the same period. Similarly, Marks \& Spencer (M\&S) engaged over 330,000 customers in a broad range of online Plan-A activities (Marks and Spencer Group PLC 2014). M\&S has long been an advocate of the value created through sustainable business practices. Through their commitment to Plan-A, an eco and ethical plan, the company has adopted more efficient processes and created new revenue streams (Marks and Spencer Group PLC 2014). Since M\&S has adopted more stringent environmental and ethical business guidelines, they have delivered a net benefit of $£ 145 \mathrm{~m}$, which has been reinvested into the business (Marks and Spencer Group PLC 2014). The American apparel brand American Eagle (AE) published a corporate social responsibility report, "AE Better World," on their website 
that detailed the company's marketing activities, including their supply chain practices, environmentally friendly activities, and responsible acts toward their associates and community (American Eagle n.d.). The report noted that they began to operate green after hearing from their associates and customers. AE explained:

We repeatedly hear from associates and clients through social media, focus groups, and internal surveys that they want us to take meaningful steps to respect our environment. Although we are still in the early stages of implementing our environmental strategy, we are encouraged by progress from our initial efforts and continue to explore additional ways to reduce our environmental footprint.

The case above shows that the fashion industry is taking the green movement seriously. Eco-friendly fashion became more widespread as the demand for eco-friendly and sustainable fashion increased. Companies are aware that green business practices enhance public image, increase both consumer and employee satisfaction, and improve profitability. Consumers started to expect eco-responsibility from fashion companies as much as they expected social responsibility. Further, sustainability allows businesses to align deeply with their missions and to engage customers on a more meaningful level (Kumar and Dholakia 2016).

What is essential for human beings' survival is the proper functioning of the eco system and all of its species. In this regard, as part of its negative effect on the eco-system, a fast-fashion system, i.e., one that captures fashion trends by moving quickly from the catwalk to the retail market (Ozdamar-Ertekin 2016), jeopardizes the existence of many animals. According to a People for the Ethical Treatment of Animals (PETA2; n.d.) report, nearly one billion rabbits are killed every year, and more than two million cats and dogs are skinned alive for their fur. In addition, Regenstein (1985, p.119) explained how reptiles have been affected:

[...] those reptiles serve a function that is much more valuable than providing hides for shoes, wallets, belts and other fashion accessories, the demand for which has driven most of these reptile species to the verge of extinction.

Additionally, fur farms have a negative impact on the eco-system through the production of feces; "phosphorus," a dangerous component of this waste, pollutes nearby rivers and streams (PETA, n.d.).

In response to these conditions, some non-profit organizations, in conjunction with animal activists and other volunteers, developed campaigns to spread awareness of the treatment of animals in the fashion 
industry. For example, in 2008, PETA teamed up with male model Austin Armacost for a campaign to target stylists, designers, and editors who keep fur visible in the fashion industry. The campaign's ad encouraged viewers to watch Tim Gunn's PETA video expose, which they could access by scanning a QR code. PETA also urged consumers to sign a petition to call for top designers - such as Marc Jacobs, Jean Paul Gaultier, Dolce \& Gabbana, and Julien MacDonald - to stop using fur in their clothing lines.

In contrast, the case of EDUN, which is a global fashion brand that produces garments in Africa with the aim to promote trade in the continent (EDUN n.d.), highlights how firms can raise consumer awareness of important issues and provide ethically produced high-end luxury garments. EDUN has launched several attractive and memorable advertising campaigns in 2012 and 2013. In EDUN's "African Shower" Spring/Summer 2013 advertising campaign, which is the continuation of their 2012 "Beautiful Rebels and Birds of Prey" campaign, elephants, the icons of Africa, are pictured with tropical rainbow colors as a symbol of renewal, rebirth, and a rare commodity. The use of an elephant also served to raise global awareness of the plight of the African elephant and, in particular, their endangered status. The founders of the brand, Bono and Ali Hewson, work with the nonprofit organization WILDAID to stop illegal wildlife trade and to raise global awareness of such trade (Dodes 2010). EDUN sells limited edition t-shirts in keeping with the themes of their campaigns and donate all proceedings to WILDAID.

\section{Fashion Cases Related to Social Well-being}

In the 1990s, Nike was accused of manufacturing its well-known products under sweatshop conditions (Paharia, Vohs and Deshpandé 2013). Beder (2002, p.24) defines such conditions as:

Using child labor, paying less than the minimum wage, enforcing overtime, and subjecting employees to verbal abuse and sexual harassment and running factories like prison camps.

The Environmental and Labor Practice Audit for Nike, which was prepared by Ernst \& Young (1997) confidentially, for company use only, was leaked to the media and resulted in massive media coverage (New York Times 1997). The report revealed that workers were paid $\$ 10$ a week and worked more hours than the legal limit (Ernst \& Young 1997). Due to Nike's unethical supply chain practices, the company was subjected to global boycotts from around the world. Protests, hunger strikes, and boycotts against Nike were utilized to raise awareness of their factory conditions, with the intent to improve the working conditions and raise 
wages (Harrison and Scorse 2004). Several universities, brought together by the Worker Rights Consortium, organized a hunger strike to protest their schools' use of Nike products (Ross 2004). Information about Nike's factory conditions spread rapidly via social media, allowing people from all over the world to share their ideas and to collaborate. As a result of such information and activities, Nike had become a symbol of sweatshop labor in the Third World and emerging markets (Beder 2002). Nike's reputation was damaged dramatically, its stock price dropped, and its sales decreased (Cushman 1998). Nike CEO Phil Knight, in a speech in 1998, after the company realized that it needed to change, noted that:

The Nike product has become synonymous with slave wages, forced overtime, and arbitrary abuse. I truly believe the American consumer doesn't want to buy products made under abusive conditions (Nisen 2013, para. 17).

Direct pressure applied to the firm by anti-sweatshop activists resulted in a wage increase of 10 to $20 \%$ for unskilled workers (Harrison and Scorse 2004). In addition, since 2005, Nike has operated with openness and transparency. Over 150 reports have been conducted by third parties on the Fair Labor Association website (www.fairlabor.org) that describe Nike's factory environments and show that activism forced Nike to change its corporate culture. This case is a good example of how giant corporations can be forced to act responsibly by ordinary consumers.

Although some fashion brand names are not involved in unethical practices in their supply chain management, suggestive and provocative visual campaigns of these brands - in terms of sexual images, nudity, racism, religion, and violence - were found offensive, or socially sensitive (Fahy et al. 1995), and socially unacceptable. A study revealed that $70 \%$ of the ads that consumers found offensive have at least one socially sensitive and unacceptable theme, which causes consumer reactions of distaste, disgust, anger, and outrage (Beard 2008). When consumers perceive an ad to be controversial, they develop negative feelings toward the brand and its products, and these adverse emotional states affect the organization's reputation (Madni, Hamid and Rashid 2016). For example, Calvin Klein (CK) has a history of banned and criticized commercials because the brand regularly communicates sexuality, nudity, violence, and rape in its advertising campaigns (Fashion Gone Rogue 2015). In 2010, the Advertising Standards Bureau in Australia ordered the removal of a CK campaign that featured Lara Stone arguing that the ad promotes gang rape (Goldwert 2010). The ad depicted Lara Stone with her head in the lap of a shirtless man in a park or urban space while surrounded by semi- 
nude men. Another shirtless man is hovering above her while one man is gripping her hair (Exhibit 1).

\section{Exhibit 1. Calvin Klein campaign in 2010 (banned)}

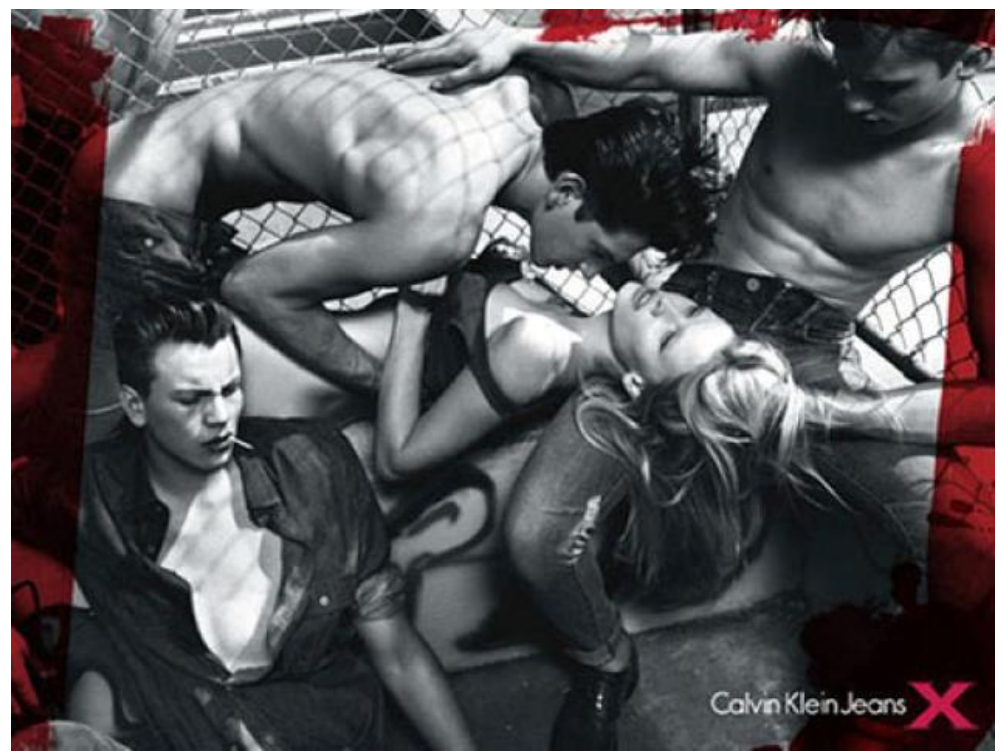

Source: This image is reproduced from Abraham (2010) under the Fair Use Act for non-commercial, academic purposes only.

Officials claimed that the image is suggestive of rape and violence, and activists, sexual assault workers, and women's groups instigated a strong, public outcry against the company (Abraham 2010). Clinical psychologist Alison Grundy, who works with sex-abuse victims, stated:

The Calvin Klein poster clearly intimat[es] the gang rape of a woman to advertise the brand. If we continue to subject future generations of young men to great barrages of aggressive, misogynist, over-sexualized and violent imagery in pornography, movies, computer games and advertising, we will continue to see the rates of sexual violence against women and children that continue unabated today. Or worse (Huffington Post 2012, para.1).

Due to consumer and official complaints, the company was forced to remove the ads from billboards (Doherty 2010). The company's reputation was damaged, and the firm faced additional marketing costs to replace the campaign's visuals.

Similarly, in 2007, the gang-rape depiction in a Dolce \& Gabbana ad prompted harsh criticism from consumers, which severely harmed the 
brand. In the ad, a woman is shown in a helpless position, pinned to the ground by a bare-chested man and surrounded by other passive, halfnaked men. The immobilized, powerless portrayal of the woman relative to the men around her evoked a perception of abuse, rape, or violence (Exhibit 2).

\section{Exhibit 2. Dolce \& Gabbana campaign in 2007 (banned)}

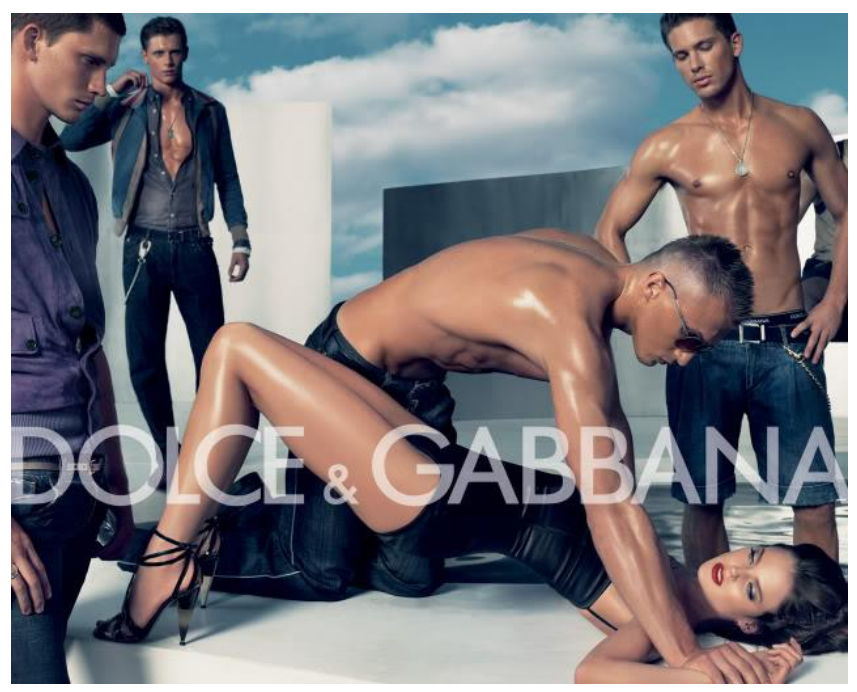

Source: This image is reproduced from the New York Daily News (2007) under the Fair Use Act for non-commercial, academic purposes only.

The Italy Advertising Self-Discipline Institute banned the Dolce \& Gabbana ad, stating, "The ad offended the dignity of the woman, in the sense that the feminine figure is shown in a degrading manner" (New York Daily News n.d.). Further, Spain's Labor and Social Affairs Ministry deemed the campaign illegal after receiving complaints from a consumer group who boycotted the brand for glorifying "chauvinist violence" (BBC News 2007). As the position of the woman's body had no relation to the products that Dolce \& Gabbana was advertising, officials determined that the ad humiliated women and promoted abuse or the idea of violence toward women (News.com.au 2007). As a result of the criticism, Dolce \& Gabbana pulled the ad worldwide (Reuters 2007). However, eight years after the ad campaign was terminated, well-known fashion publicist Kelly Cutrone posted the ad to her Twitter account, whereupon it regained public attention. Many followers commented on the post, declaring the ad disgusting and horrifying (Moss 2015). Three followers' comments on Twitter are presented in Exhibit 3. 


\section{Exhibit 3. Users' comments on Twitter for Dolce \& Gabbana ad}

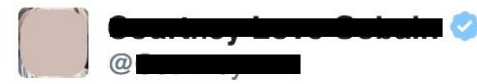

Follow

Just round up all my Dolce \& Gabbana pieces, I want to burn them. I'm just beyond words and emotions. Boycott senseless bigotry! \#boycottD\&G

6:09 AM - 15 Mar 2015

h 2 ᄂ7 $857 \cup 1,195$

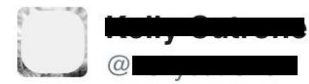

Follow

Just arrived LA. Wish I were home so I could make a video of myself cutting up my @dolcegabbana clothes! \#boycottDG

12:06 AM - 16 Mar 2015

h $\quad$ เ7 $75 \cup 137$

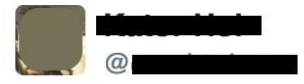

Follow

@@dolcegabbana looks like a

gang rape, no less. Family values, and shit.

1:17 AM - 16 Mar 2015

\& 27201

Source: This image is reproduced from www.twitter.com under the Fair Use Act for non-commercial, academic purposes only.

In an ever-changing and highly globalized world, religion continues to play a significant role in forming social norms and consumer behavior (Fam, Waller and Erdogan 2004). In general, research supports the notion that religious people are conservative (Barton and Vaughan 1976) and have great concern for moral standards (Wiebe and Fleck 1980), and their attitudes are shaped by traditional values (Wilkes et al. 1986). Luqmani, Yavas and Quraeshi (1987) believe that firms should obtain permission and approval from religious authorities to launch provocative and unconventional marketing communication and advertisement campaigns. Peebles and Ryans (1984) highlighted the importance of creating advertising campaigns that match society's sociocultural environment, and failure to create such a campaign would likely cause a negative attitude 
toward the advertisement and the brand (Gardner, 1985). For instance, in 2005, France's Girbaud Fashion House, founded by Marithé and François Gribaud, recreated Leonardo da Vinci's The Last Supper with an almost all-female cast who mimic Christ and his apostles. There is only one male model, presenting John the Apostle, who sits on a woman's lap, naked from the waist up and wearing only low-waisted Girbaud jeans. All women are dressed in fashionable attire (Exhibit 4).

\section{Exhibit 4. Girbaud Fashion House's The Last Supper, in 2005 (banned)}

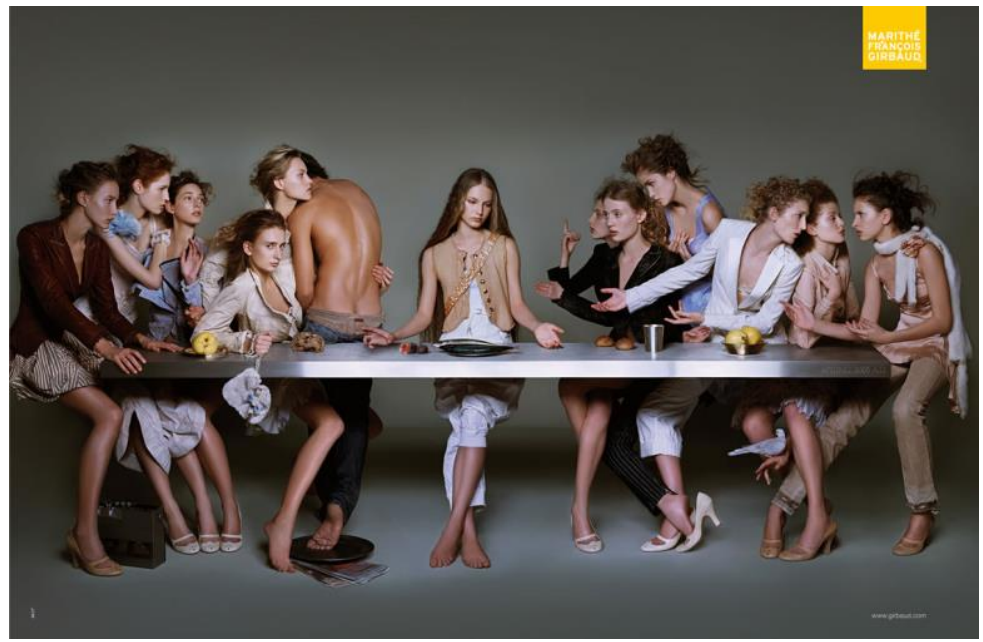

Source: This image is reproduced from the New York Daily News (n.d.) under the Fair Use Act for non-commercial, academic purposes only.

Under pressure from the Catholic Church, Italy banned the ad (Ichikawa 2008). The Advertising Standards Authority of Italy stated:

This Last Supper inevitably recalls the very foundations of the Christian faith. This kind of image, with a high concentration of theological symbols, cannot be recreated and parodied for commercial ends without offending the religious sensitivities of at least part of the population... One of the women apostles is kissing the naked torso of a man, which just makes the imitation more offensive... As does the use of Christian symbols like the dove, the chalice and the position of the fingers of the female Christ (Arie 2005).

The Advertising Standards Authority of Italy explained that they found the image offensive because it attempts to elevate materialism to the same level as that of religious symbols (Ads of the World 2005). The 
message of the advertisement subverted the boundaries between the sacred and the profane, offending consumer sensibility and drawing an adverse reaction from consumers. It was first banned in Milan, and the ad was then found to violate French blasphemy laws; the Girbaud Fashion House was ordered to remove the ad within three days or risk massive fines (Mallia 2009).

The use of retouched body images is another area that causes controversial reactions from consumers. The growing use of photoshopping in advertisements has led to an increase in female eating disorders, which forced some fashion brands to take responsibility for the retouched images in their campaigns (Donovan 2012). For example, in 2009, a Ralph Lauren ad campaign featured model Filippa Hamilton (Exhibit 5), whose image was airbrushed to portray a skeleton-like waist that was smaller than her head. Hamilton criticized Ralph Lauren for digitally altering her image and then claimed that the firm fired her for being overweight (she was 5 feet 10 inches tall and weighed 120 pounds) and unable to fit into their clothes (The Telegraph 2009). After receiving negative comments and calls for boycotts from consumers (Exhibit 6), the company removed the ad from the Internet and apologized to the public:

We have learned that we are responsible for the poor imaging and retouching that resulted in a very distorted image of a woman's body. We have addressed the problem and going forward will take every precaution to ensure that the calibre of our artwork represents our brand appropriately (Today 2009, para. 8).

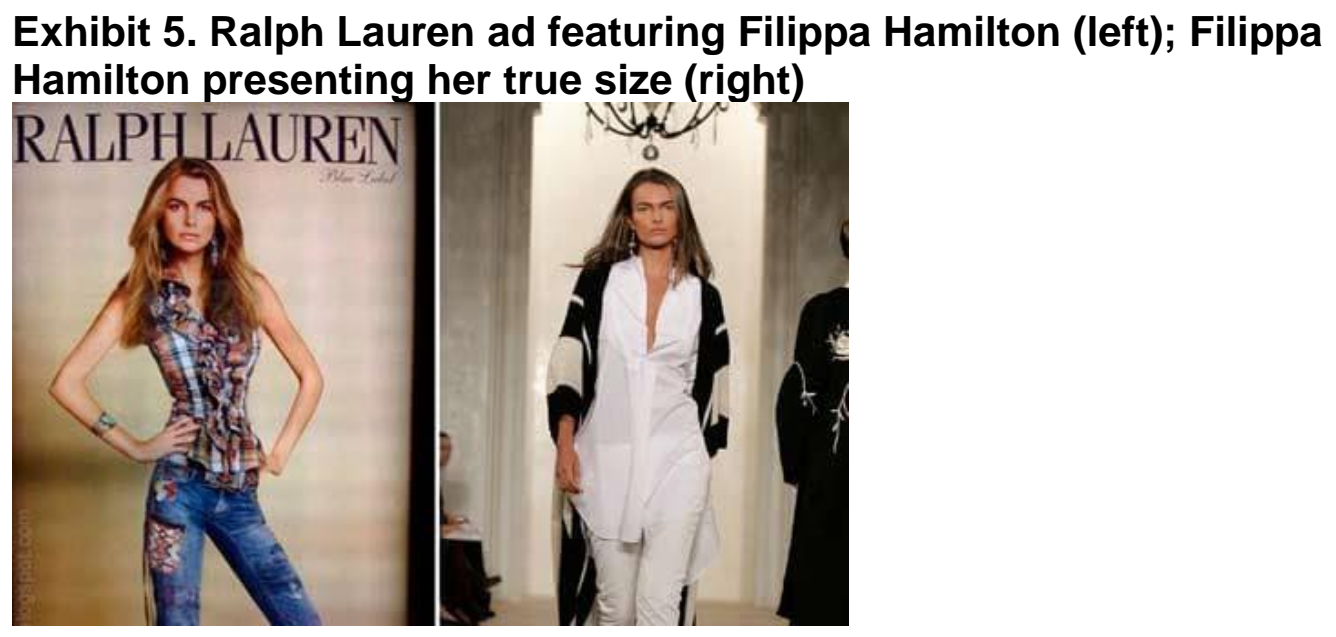

Source: This image is reproduced from The Telegraph (2009) under the Fair Use Act for non-commercial, academic purposes only. 


\section{Exhibit 6. Consumer comments under Ralph Lauren ad featuring Filippa Hamilton in 2009}

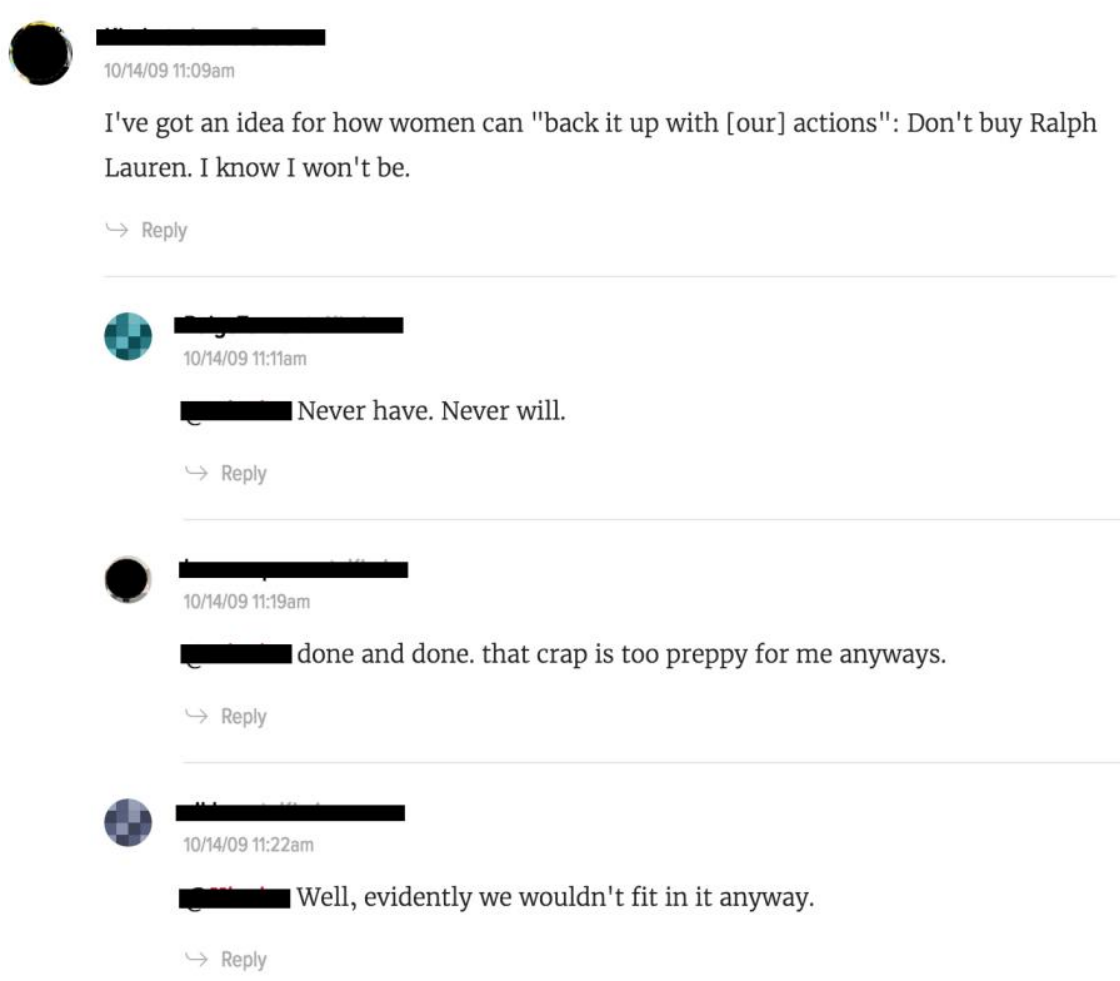

Source: This image is reproduced from Sauers (2009) under the Fair Use Act for non-commercial, academic purposes only.

Similarly, in 2010, Revolve Clothing, a leading fashion e-commerce site headquartered in Los Angeles, CA, USA, repeatedly featured on their website a skeletal-looking Allie Crandell, modeling BCBG Max Azria clothing, until consumers complained that images of her could not be real and must have been photoshopped (Carmon 2010). Crandell however was, indeed, as thin as the photos depicted. Nevertheless, the model's image of her tiny waist and extremely thin arms (Exhibit 7) sparked outrage among consumers (Rawi 2010). One of the users commented:

I can't believe Revolve would think that this model is a good representation of them. If you want people to buy from your company, don't make them feel bad by showing your clothing on someone who clearly has no self-esteem or respect for their body (Mandell 2010). 
In response to consumer criticism, Revolve issued the following public statement on their website, promising to work in close collaboration with Crandell to get her to a healthier size:

$\mathrm{Hi}$ everyone, thank you for your concern. We are absolutely aware of the feedback and responses to our model's weight and it has concerned us as well. We are working closely with both the model and her agent to get her to a healthier size. She won't be appearing in any of our new product batches or in any of our fashion editorial photos moving forward until the issue is adequately addressed. We appreciate and respect input from our customers and visitors and hope that you find our responses satisfying. We have been attempting to respect the privacy of the model in question while dealing with the issue on our end. We hope you understand. Sincerely, The Revolve Team (Huffington Post, 2010, para 3).

Customers, however, were not satisfied by the firm's response. They warned that if Crandell's picture remained on the website, they would continue to boycott the brand (Mandell 2010).

\section{Exhibit 7. Revolve ad featuring Allie Crandell, and user comments regarding her image, on Revolve website}

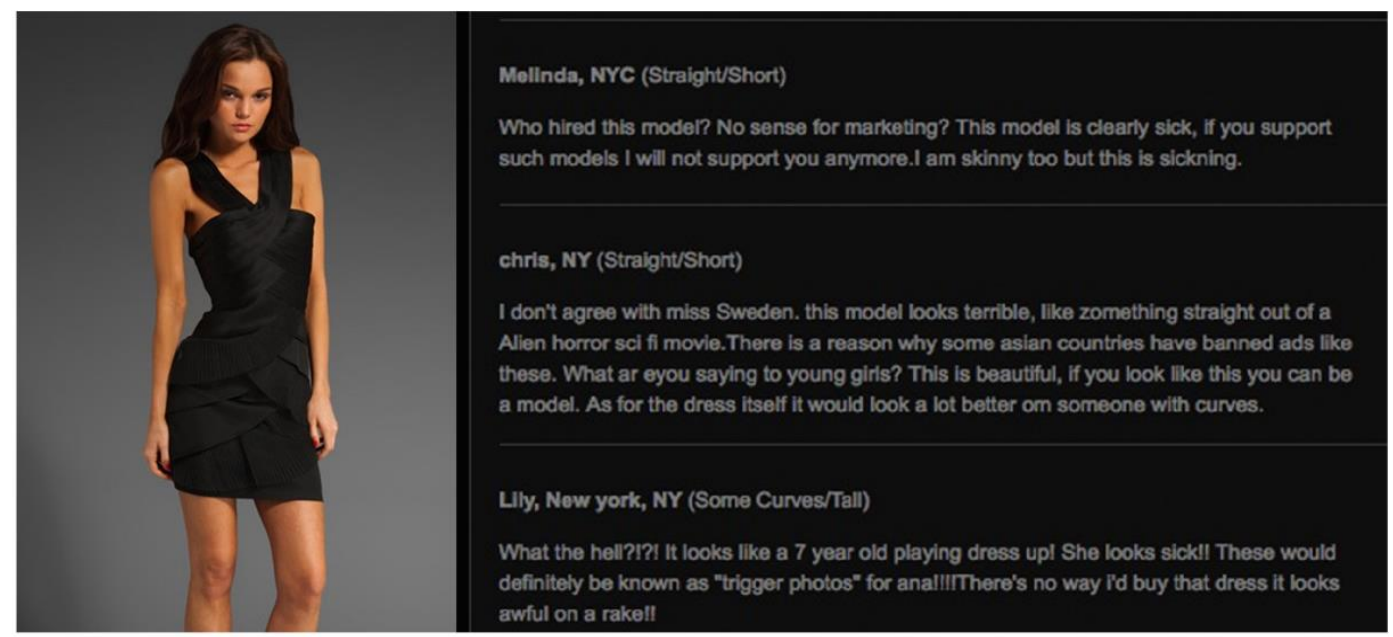

Source: This image is reproduced from Carmon (2010) under the Fair Use Act for non-commercial, academic purposes only.

Cardiff (2012) reported that, contrary to common belief in the fashion industry, women who were faced with images of overly skinny women, not reflective of their real size, decreased their purchase intentions by approximately $60 \%$; further, women who were larger than a 
size 6 decreased their purchase intentions by $76 \%$. In addition, the author noted that consumers increase their purchase intentions by over $175 \%$ when they see models who better reflect consumers' age. Consistent with these findings, LK Bennett, a luxury fashion brand based in London, England, turned to "real women" rather than professional models to launch its autumn/winter collection on the brand's 20th anniversary in 2010 (Waite 2010). The brand recruited four women from different ages and backgrounds to act as brand ambassadors and appear in press advertisements (Gordon 2011). The campaign presented women wearing LK Bennett footwear, clothing, and accessories in a variety of working environments, with the slogan Life is the Occasion (Clark 2010). The retailer invited consumers to audition to be the face of its next marketing campaign. LK Bennett set a good example by featuring real women with realistic body sizes in its marketing campaign, which, in turn, allows the company to enjoy a better relationship with female consumers.

Several fashion brands and nonprofit organizations have been working to raise awareness of the use of skeletal-looking models in the fashion industry. For example, in 2007, Italian fashion brand Nolita used Isabelle Caro, a French model and actress, for its ad campaign to create awareness of eating disorders among models (Grimes 2010). Isabelle had been suffering from anorexia since she was 13 , and at the time, she was 5 feet 4 inches tall and weighed 68 pounds (Daily Mail 2010). Her very paleskinned, skeletal image, with her backbone and facial bones very pronounced, teeth seemingly too large for her mouth, and arms and legs all skin and bones, shocked viewers (see Exhibit 8). "No-Anorexia" was written on the top of the photograph. Ms. Caro stated, before she died at age 28:

The idea was to shock people into awareness. I decided to do it to warn girls about the danger of diets and of fashion commandments (Grimes 2010, para.7).

The posters stunned and fascinated people, raising worldwide awareness of the issue. Ms. Caro was invited as a guest speaker on various TV shows and appeared in documentaries in France, Britain, the United States, and Japan (Lichfield 2011). In their campaign, Nolita claimed that they spoke for the consumers who were "real women," particularly those affected by popular images of thinness (Ferreday 2011).

Similarly, to stop the fashion industry from digitally editing models to look like skeletons, Brazilian modeling agency Star Models launched a creative eating disorder, anti-anorexia awareness campaign with the tag line, "You are not a sketch. Say no to Anorexia," in 2013 (Krupnick 2013). 
The agency presented a typical fashion sketch, with drawn exaggerated proportions and long lines on the left, and, on the right, real models with airbrushed looks similar to the illustration (Exhibit 9).

\section{Exhibit 8. Ad by Italian fashion brand Nolita, featuring model Isabelle} Caro, to create awareness about eating disorders among models

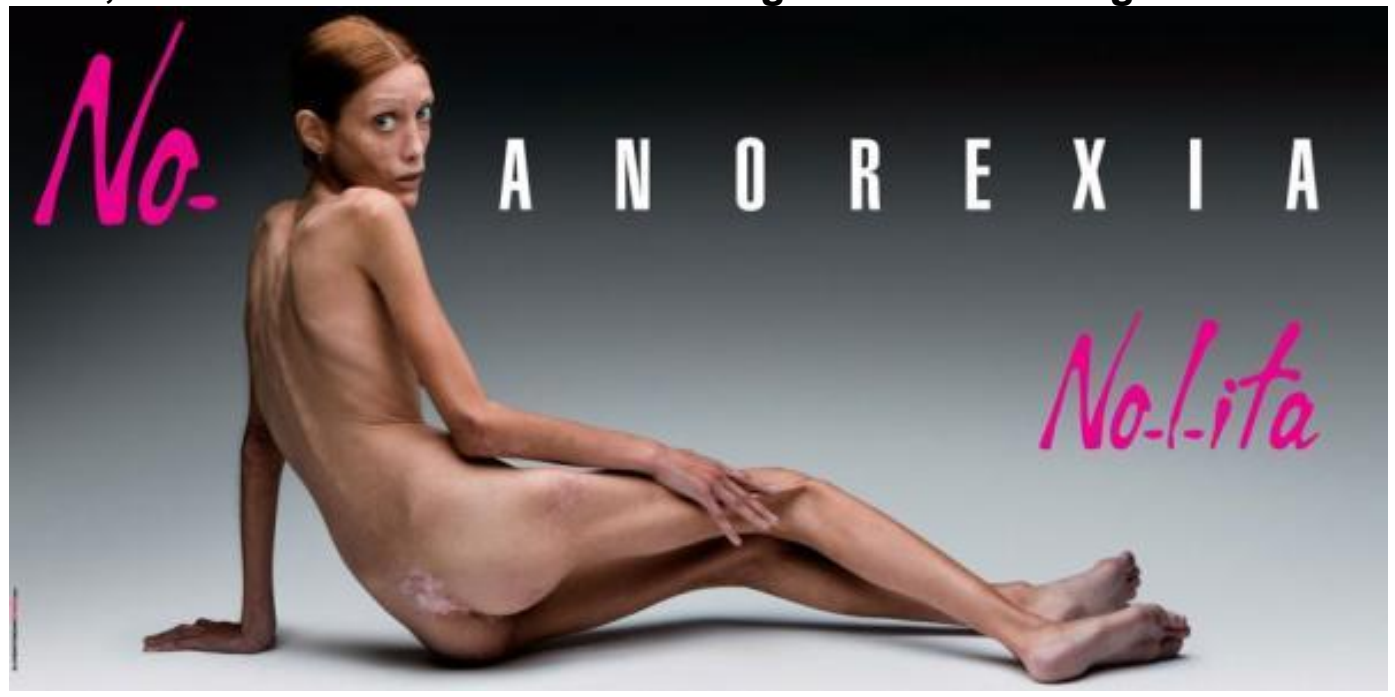

Source: This image is reproduced from Daily Mail (2010) under the Fair Use Act for non-commercial, academic purposes only.

\section{Exhibit 9. Star Models' "You are not a sketch" campaign in 2013}
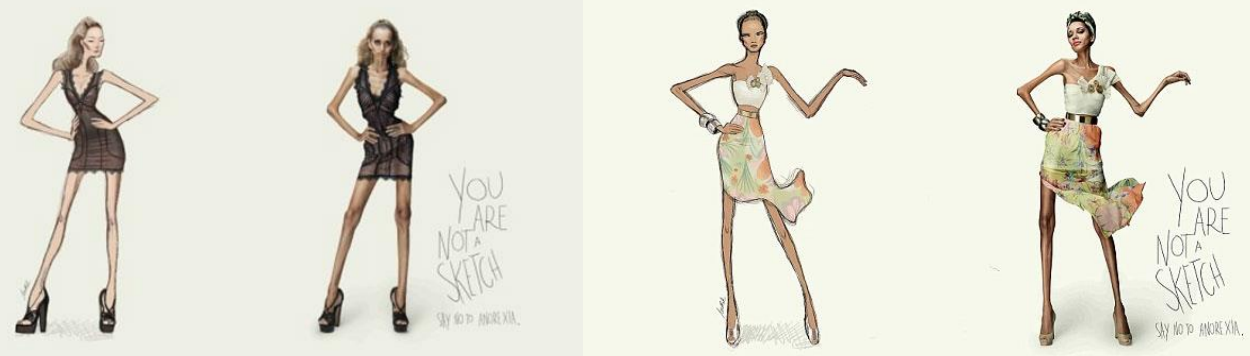

Source: This image is reproduced from Krupnick (2013) under the Fair Use Act for non-commercial, academic purposes only.

The graphic ad campaign raised awareness among consumers, who commented against "thinspiration" blogs and pro-anorexia websites:

It sends a powerful message... It's a literal visualization of what the fashion industry sets the standards at (female commenter). 
I like these ads because they address the issue that anorexia seems to stem from the inability for people to distinguish reality from fiction (male commenter) (Daily Mail 2013, para. 36).

In summary, both Nolita and Star Models created campaigns that served as an important anti-anorexia public service announcement and used shocking images to convey its message to the public.

Finally, several fashion brands gained consumer support and increased brand awareness and revenue through their individual actions to improve the well-being of society. For example, products featured in Dove's "Real Beauty" campaign in 2004, where donations are made to the Dove Self-esteem Fund, showed an increase in sales of $600 \%$ two months after the campaign started, and $20 \%$ in the subsequent year (Gibbons 2009). Similarly, Aldo Shoes and YouthAIDS created a successful integrated marketing campaign in 2005 titled, "Hear No Evil, See No Evil, Speak No Evil" to fight against HIVIAIDS around the world. Celebrities such as Salma Hayek, Ashley Judd, Christina Aguilera, Avril Lavigne, Ludacris, and Charlize Theron took part in these campaign ads (Rahimi 2005). The promotion asked shoppers to purchase a $\$ 5$ tag in addition to the shoe purchase, with $100 \%$ of the proceeds' going to YouthAIDS, which raised more than $\$ 3$ million by the end of the campaign (PSI Annual Report 2007). The results, however, were not only monetary in nature. Aldo created an emotional connection with consumers and experienced an increase in shoe sales and foot traffic in stores; and the website www.youthaids-aldo.org received more than 15,000 visitors per day and raised over 1.5 billion editorial impressions in leading media outlets, such as the Chicago Sun-Times, The Washington Post, US Weekly, People, and Elle (Kerjan 2012).

\section{Conclusion}

In this paper, the second and final of the larger study, we discussed the positive and negative impacts of ethical marketing practices on consumers and fashion companies' bottom line. We have examined selected highprofile cases related to different concerns, including environmental issues, body image usage, respect for cultural and social values, fair labor practices, treatment of animals, and charitable contributions. While some companies have built their business and brand image through the use of unethical marketing activities, others have chosen to focus their efforts on "ethical fashion marketing". From an ethical standpoint, their marketing activities are aimed at reflecting society's views of what is morally right. These firms' cultures have, in fact, evolved to remain in line with changing societal values, as reflected in the greater emphasis on ethics and social 
responsibility.

The cases we use show that, when a fashion brand is perceived as controversial, consumers' behavior and the brand's corporate reputation are negatively affected. On the other hand, companies are rewarded relatively quickly with sales and positive publicity when they produce merchandise that meets or exceeds ethical standards. An ethical brand enhances the firm's reputation and this, in turn, reinforces the brand and its performance in the global marketplace. Conversely, seemingly unethical practices can severely damage or even destroy the entire brand image, as evidenced in several of the cases reviewed in this paper.

Fashion companies do, in fact, achieve a competitive advantage over others in the large fashion market, based on their ethical stance. They also can leverage their moral stance to differentiate themselves from other companies using their brand communication and identity. When firms invest adequately in socially responsible practices and adhere to high ethical standards in their production systems and branding campaigns, they can reap benefits in the form of a stronger and more favorable reputation and a more loyal customer base.

For many firms, the issue does not simply mean "doing the right thing." In the case of supply chain practices, and for many multinational enterprises (MNEs), it may be nearly impossible to have a full grasp of the supply chain structure and all of its units, especially given the large number of contractors and subcontractors of the firm and its key suppliers. With increasing mergers and acquisitions, ever-more demanding consumers, and mounting pressures to reduce costs, a firm can be faced with the monumental task of mapping out its entire supply chain and monitoring all of the players involved in it on a regular basis. Some firms, such as Apple and Walmart, have spearheaded various initiatives to promote supply-chain transparency and hold first-, second-, and even third-tier suppliers accountable for any unethical practices. Global MNEs, concerned about their brand perception, have even started a certification program, whereby suppliers must show how they adhere to high standards of social responsibility before they can be selected as long-term providers. We believe that leaders, such as Apple, can serve as role models and provide benchmarks that fashion industry firms can leverage in this area. Investigating best practices in managing supply chains and their transferability and adaptation in the fashion industry is an area that we believe offers significant topics for further research.

There are also practical challenges in adhering to cultural and societal values and norms in marketing and advertising in the fashion industry. By default, fashion designers are always on the lookout for new 
preferences and trends. Bringing something fresh and new and being the first mover in the market could be the key to success. As such, adhering to widely accepted values and norms may, in fact, be a limiting factor for firms when they seek to be trendsetters. Here, generational issues may be a concern. While younger generations may be open to change and to taking a risk even if it entails behaviors outside the realm of what is considered normal or acceptable, older generations may be less willing to accept what could seen as deviant practices. Here, firms need to consider their options carefully and strike a balance between innovation and creativity on the one hand and morals and norms on the other. Crosscultural and cross-generational similarities and differences in perceptions of branding and advertising practices may be an area that also warrants further research.

As this study reveals, there is a strong relationship between ethical branding, corporate reputation, and financial performance. There are nonetheless a number of questions that remain unanswered. For example, what is the role of demographic factors (e.g., millennials, gender, urbanization) in how consumers react to important ethical issues in the fashion industry? Further, purchase or boycott intentions and actual behavior are two different things. Consequently, the degree that intentions translate into actual practice for various types of concerns is an issue that requires further study.

Through our review of high-profile cases related to ethical fashion concerns, we hope to provide additional insight for advertisers and marketing practitioners in the fashion industry. The underlying theme in our cases is that fashion firms as well as marketing and branding professionals need to be aware of the fact that consumers care about ethics and expect them to be an integral component of the enterprise's strategy, culture, systems, and practices. At the same time, global firms that operate in multiple, and often maximally different, cultural and institutional settings face the added challenges of managing and responding to various consumer expectations. Consequently, cultural knowledge and awareness are essential to designing and implementing culturally sensitive strategies in the fashion industry, i.e., advertising that is morally and ethically acceptable in one country may be offensive or unacceptable in another. Failure to design context-specific, culturally sensitive marketing strategies can easily damage a brand's image beyond repair. In closing, according to Henthorne and LaTour (1994, p. 88), "As the ethical considerations of society change over time, what is considered appropriate and acceptable in advertising must also change." 


\section{References}

Abraham, T. (2010), "Lara Stone's Calvin Klein Jeans ad banned in Australia for being suggestive of violence and rape", (accessed November 27, 2016), [available at http://www.dailymail.co.uk/femail/ article-1322815/Lara-Stone-Calvin-Klein-Jeans-ad-banned-

Australia-suggestive-rape.html]

Ads of the World. (2005), "Last supper", (accessed December 1, 2016), [available at https://adsoftheworld.com/media/print/last supper 1]

American Eagle (n.d.), "AE Better World", (accessed November 27, 2016), [available at http://www.ae.com/Images/corpResp/AEBetter WorldNew.pdf]

Arie, S. (2005), "Milan bans Da Vinci parody", (accessed December 1, 2016), [available at https://www.theguardian.com/world/2005/feb 104/media.arts]

Barton, K. and Vaughan, G. (1976), "Church membership and personality", Social Behaviour and Personality, 4, 11-16.

BBC News (2007), "Censored' ad sparks row in Spain", (accessed December 1, 2016), [available at http://news.bbc.co.uk/2/hi/ business/6448421.stm]

Beard, F. K. (2008), Humor in the Advertising Business: Theory, Practice, and Wit. Lanham, Maryland, USA: Rowman and Littlefield Publishers.

Beder, S. (2002), "Putting the Boot In", The Ecologist, 32 (3), 24-28, 6667.

Bonoma, T. (1985), "Case research in marketing: opportunities, problems, and a process", Journal of Marketing Research, 12, 199-208.

Cardiff, A. (2012), "Thin Models Actually Don't Make Most Women Buy Clothes", May 16, (accessed March 22, 2015), [available at http://www.thegloss.com/2012/05/16/fashion/thin-models-studywomen-buying-trend-752/\#ixzz3J4OVGVZW]

Carmon, I. (2010), "Fashion Site Promises Not To Hire Model Til She Gains Weight", (accessed December 1, 2016), [available at http://jezebel.com/5717528/fashion-site-promises-not-to-hiremodel-til-she-gains-weight] 
Cavusoglu L. and Dakhli M. (2016), "The Impact of Ethic Concerns on Fashion Consumerism: A Review", Markets, Globalization \& Development Review: Vol. 1, No. 2, Article 5.

Clark, N. (2010), "LK Bennett to roll out 'real women' campaign", (accessed December 1, 2016), [available at http://www.campaignlive.co.uk/article/1019477/lk-bennett-roll-realwomen-campaign]

Cushman Jr, J. (1998), "Nike pledges to end child labor and increase safety", May 13, (accessed November 22, 2016), [available at http://www.nytimes.com/1998/05/13/business/internationalbusiness-nike-pledges-to-end-child-labor-and-apply-us-rulesabroad.html]

Daily Mail (2010), "Anorexic model who appeared in shock fashion campaign dies at 28", (accessed December 3, 2016), [available at http://www.dailymail.co.uk/femail/article-1342580/Anorexic-modelIsabelle-Caro-appeared-shock-fashion-campaign-dies-28.html]

Daily Mail (2013), "Powerful anti-anorexia ad campaign tells women 'you are not a sketch' using models with fashion illustration proportions", (accessed December 3, 2016), [available at http://www.dailymail.co.uk/femail/article-2311770/Powerful-antianorexia-ad-campaign-tells-women-sketch-using-models-fashionillustration-proportions.htm]

Dodes, R. (2010), "Out of Africa, Into Asia", (accessed December 3, 2016), [available at https://www.wsj.com/articles/SB1000142405274870435890457547 8310504593870]

Doherty, E. (2010), "Advertising watchdog orders violent Calvin Klein ads to be taken down", (accessed November 30, 2016), [available at http://www.heraldsun.com.au/archive/news/violent-ads-spark-sexfury/story-e6frf7l6-1225940899235]

Donovan, K. C. (2012), "Vanity Fare: The Cost, Controversy, and Art of Fashion Advertisement Retouching", Notre Dame Journal of Law, Ethics \& Public Policy, 26 (2), 581-620.

EDUN. (n.d.), About, EDUN official website, (accessed November 30, 2015), [available at http://edun.com/pages/about]

Eisenhardt, K.M. (1989), "Building theories from case study research", Academy of Management Review, 14 (4), 532-550. 
Ernst \& Young (1997), "Ernst \& Young Environmental and Labor Practice Audit", (accessed November 29, 2016), [available at http://www.corpwatch.org/article.php?id=2488]

Fahy, J., Smart, D., Pride, W. and Ferrell, O. (1995), "Advertizing sensitive products", International Journal of Advertising, 14, 231-243.

Fam, K. S., Waller, D. S. and Erdogan, B. Z. (2004), "The influence of religion on attitudes towards the advertising of controversial products", European Journal of Marketing, 38 (5/6), 537-555.

Fashion Gone Rogue (2015), “Calvin Klein's Most Controversial Campaigns Through The Years", (accessed November 29, 2016), [available at http://www.fashiongonerogue.com/calvin-kleincontroversial-campaign-images/]

Ferreday, D. (2011), "Haunted Bodies: Visual cultures of anorexia and size zero", Borderlands ejournal, 10 (2), 1-22.

Gardner, M. (1985), "Mood states and consumer behavior: a critical review", Journal of Consumer Research, 12, 251-267.

Gibbons, G. (2009), "The Social Value of Brands," in Brands and Branding, Rita Clifton et. al., ed. New York: The Economist/Bloomberg, 45-60.

Goldwert, L. (2010), "Lara Stone's new Calvin Klein ad banned - standards board says image promotes violence and rape", (accessed November 30, 2016), [available at http://www.nydailynews.com/lifestyle/fashion/lara-stone-new-calvin-klein-ad-banned-standardsboard-image-promotes-violence-rape-article-1.188948]

Gordon, J. (2011), "At last fashion gets real: Meet the stars of LK Bennett's latest campaign", (accessed December 2, 2016), [available at http://www.dailymail.co.uk/home/you/article1346149/Meet-stars-LK-Bennetts-latest-fashion-campaign.html]

Grimes, W. (2010), "Isabelle Caro, Anorexic Model, Dies at 28", (accessed December 3, 2016), [available at http://www.nytimes.com/2010/ 12/31/world/europe/31caro.html]

Harrison, A. and Scorse, J. (2004), "The Nike Effect: Anti-Sweatshop Activists and Labor Market Outcomes in Indonesia", working paper.

Huffington Post (2010), "Allie Crandell Sidelined by Revolve Clothing Over Weight Concerns", (accessed December 1, 2016), [available at 
http://www.huffingtonpost.com/2010/12/22/allie-crandell-revolve n 800476.html]

Ichikawa, S. (2008), "Creative Industries: The Case of fashion", in The Cultures and Globalization Series: The Cultural Economy, H. K. Isar, ed. SAGE Publications, 253-260.

Kent, B. (2007-2008), "Innovation and the Organic Textile Processing", (accessed November 11, 2015), [available at http://kennisbank.hva.nl/document/219293]

Kerjan, E. (2012), "Creating Value through Cause-Related Marketing and Celebrity Advocacy: The Case of YouthAIDS \& PSI", (accessed November 12, 2016), [available at http://opim.wharton.upenn.edu/risk/library/WP201202 RiskCtr YouthAIDS-PSI.pdf]

Kumar, B. and Dholakia, N. (2016), "Toward Pro-Sustainability Actions: A Macro-Behavioral Perspective", Review of Marketing Research, Vol. 13; In Marketing in and for a Sustainable Society, Naresh K. Malhotra, ed. Emerald Group Publishing Limited, 169-192.

Krupnick, E. (2013), "Anti-Anorexia Ads Stun With Tagline - You Are Not A Sketch" (accessed December 2, 2016), [available at http://www.huffingtonpost.com/2013/04/18/anti-anorexia-adsphotos $\mathrm{n}$ 3110649.html]

LaTour, M. S. and Henthorne, T. L. (1994), "Ethical judgments of sexual appeals in print advertising", Journal of Advertising, 23, 81-90.

Lichfield, J. (2011), "Isabelle Caro: Anorexia sufferer who appeared in a global campaign against the disorder", (accessed December 3, 2016), [available at http://www.independent.co.uk/news/obituaries/isabelle-caroanorexia-sufferer-who-appeared-in-a-global-campaign-against-thedisorder-2185196.html]

Luqmani, M., Yavas, U. and Quraeshi, Z. (1987), "Advertising in Saudi Arabia: content and regulation", International Journal of Advertising, 6 (1), 59-71.

Madni, A., Hamid, N. and Rashid, S. M. (2016), "Influence of Controversial Advertisement on Consumer Behavior", The Journal of Commerce, $8(1-2), 14-24$. 
Mallia, K. L. (2009), "From the Sacred to the Profane: A Critical Analysis of the Changing Nature of Religious Imagery in Advertising", Journal of Media and Religion, 8, 172-190.

Mandell, N. (2010), "Too skinny? Allie Crandell's rib-baring appearance sparks debate on fashion website", (accessed December 1, 2016), [available at http://www.nydailynews.com/life-style/skinny-alliecrandell-rib-baring-appearance-sparks-debate-fashion-websitearticle-1.474443]

Marks and Spencer Group PLC. (2014), "Annual report and financial statements 2014", (accessed December 13, 2015), [available at http://annualreport.marksandspencer.com/downloads/MS AR2014 Strategic Report.pdf]

Merriam, S. B. (1998), Qualitative research and case study applications in education. San Francisco: Jossey-Bass.

Miles, M.B. and Huberman, A. M. (1994), Qualitative data analysis: An Expanded Sourcebook of New Methods, (2nd ed.), Thousand Oaks, CA: Sage.

Moss, R. (2015), "Gang Rape Dolce \& Gabbana Advert Brings Yet More Controversy For Brand After Synthetic" (accessed December 1, 2016), [available at http://www.huffingtonpost.co.uk/2015/03/18/ dolce-and-gabbana0gang-rape-advert n 6893044.html]

New York Daily News. (n.d.), "Most controversial ads that have been banned", (accessed December 1, 2016), [available at http://www.nydailynews.com/entertainment/controversial-bannedads-gallery-1.2245644]

New York Times (1997), "Nike Shoe Plant in Vietnam Is Called Unsafe for Workers" (accessed November 29, 2016), [available at http://www.nytimes.com/1997/11/08/business/nike-shoe-plant-invietnam-is-called-unsafe-for-workers.html]

News.com.au. (2007), “'Gang rape' Dolce and Gabbana advert banned”, (accessed December 1, 2016), [available at http://www.news.com.au/national/gang-rape-dolce-and-gabbanaadvert-banned/story-e6frfkp9-1111113111890]

Niinimäki, K. (2010), "Eco-clothing, consumer identity and ideology", Sustainable Development, 18 (3), 150-162.

Nike, Inc. (2012-2013), "Sustainable Business Performance Summary", (accessed December 1, 2016), [available at 
https://www.unglobalcompact.org/system/attachments/81781/origin al/FY12-13 NIKE Inc CR Report.pdf?1400276890 ]

Nisen, M. (2013), "How Nike Solved Its Sweatshop Problem", (accessed November 29, 2016), [available at http://www.businessinsider.com/ how- nike- solved-its-sweatshop-problem-2013-5]

NY Daily News (2007), "Most Controversial Banned Ads", (accessed November 27, 2016), [available at http://www.nydailynews.com/entertainment/controversial-bannedads-gallery-1.2245644?pmSlide $=1.2245630]$

Ozdamar-Ertekin, Z. (2016), "Conflicting Perspectives on Speed: Dynamics and Consequences of the Fast Fashion System", Markets, Globalization \& Development Review, Vol. 1: No. 1, Article 6.

Paharia, N., Vohs, K. D. and Deshpandé, R. (2013), "Sweatshop labor is wrong unless the shoes are cute: Cognition can both help and hurt moral motivated reasoning", Organizational Behavior and Human Decision Processes, 121, 81-88.

Patton, M. Q. (1990), Qualitative evaluation and research methods. Newbury Park, CA: Sage.

Peebles, D. and Ryans, J. (1984), Management of International Advertising, Allyn and Bacon, Boston, MA.

PETA (n.d.), "Inside the Fur Industry: Factory Farms", (accessed November 11, 2016), [available at http://www.peta.org/issues/ animals- used-for-clothing/animals-used-clothing-factsheets/insidefur-industry-factory-farms/]

PETA2 (n.d.), "Why Animal Rights?”, (accessed November 12, 2016), [available at http://www.peta.org/about-peta/why-peta/why-animalrights/]

PSI Annual Report. (2007), PSI Annual Report 2007, (accessed November 11, 2016), [available at http://www.psi.org/wpcontent/uploads/drupal/sites/default/files/publication files/PSIAnnual-Report07.pdf]

Rahimi, S. (2005), "An Enduring Ribbon of Stars", (accessed December $3, \quad 2016), \quad$ [available at http://www.nytimes.com/2005/11/10/ nyregion /an-enduring-ribbon-of-stars.html? $\quad r=0]$ 
Rawi, M. (2010), "The City star banned from fashion website after shocked readers complain about her stick-thin frame", (accessed December 3 , 2016), [available at http://www.dailymail.co.uk/femail/article1341168/The-City-star-banned-fashion-website-Revolve-shockedreaders-complain-stick-frame.html\#ixzz4RcoxgREe]

Regenstein, L. (1985), "Animal rights, endangered species and human survival", in In Defence of Animals, P.Singer, ed. New York: Basil Blackwell, 118-132.

Remenyi, D., Williams, B., Money, A. and Swartz, E. (1998), Doing research in business and management. An introduction to process and method. London: Sage.

Reuters. (2007), "Dolce \& Gabbana bow to criticism and pull ad", (accessed December 1, 2016), [available at http://www.reuters.com/article/us-italy-dolcegabbana-advertidUSL0631454820070306]

Ross, R. (2004), "From Antisweatshop to Global Justice to Antiwar: How the new New Left is the Same and Different From the old New Left", Journal of World-Systems Research, 287-319.

Sauers, J. (2009), "Ralph Lauren Fires Photoshopped Model For Being Too Fat", (accessed December 1, 2016), [available at http://jezebel.com/5381381/ralph-lauren-fires-photoshopped-modelfor-being-too-fat]

Stake, R.E. 1994, Case Studies: Handbook of Qualitative Research. Sage, Thousand Oaks.

Stake, R. E. (2000), The case study method in social inquiry, In, Case study method: Key issues, key texts, R. Gomm, M. Hammersley and P. Foster, Eds. London: Sage, 20-26. (Original work published 1978 Educational Researcher (7), 5-8.

Teddlie, C. and Yu, F. (2007), "Mixed Methods Sampling: A Typology With Examples", Journal of Mixed Methods Research, 1 (77), 77-100.

The Huffington Post (2012), "Calvin Klein Billboard Banned For Being Suggestive Of Violence And Rape", (accessed November 30, 2016), [available at http://www.huffingtonpost.com/2010/10/21/ calvin-klein-billboard-ba n 771559.html]

The Telegraph (2008), "African elephants face extinction by 2020, conservationists warn”, August 4, (accessed November 26, 2016), 
http://www.telegraph.co.uk/earth/earthnews/3348683/ Africanelephants-face-extinction-by-2020-conservationists warn.html]

The Telegraph (2009), "Model fired by Ralph Lauren for being too fat", (accessed November 26, 2016), [available at http://www.telegraph.co.uk/news/worldnews/northamerica/usa/6330 961/Model-fired-by-Ralph-Lauren-for-being-too-fat.html]

TODAY (2009), "Size 4 model: I was fired for being too fat," October 14, (accessed November 22, 2016), [available at http://www.today.com/id/33307721/ns/today-today style/t/sizemodel-i-was-fired-being-too-fat/\#.VH-nNYeJnww]

Waite, A. (2010), "LK Bennett's real women", (accessed December 2, 2016), [available at http://fashion.telegraph.co.uk/newsfeatures/TMG7926035/LK-Bennetts-real-women.html]

Wiebe, K. and Fleck, J. (1980), "Personality correlates of intrinsic and extrinsic and non-religious orientations", Journal of Psychology, 105, 181-187.

Wilkes, R., Burnett, J. and Howell, R. (1986), "On the meaning and measurement of religiosity in consumer research", Journal of the Academy of Marketing Science, 14 (1), 47-56.

Yin, R. K. (1994), Case Study Research Design and Methods, Applied Social Research Methods Series Volume 5, 2nd ed., Sage Publications.

Zainal, Z. (2007), "Case study as a research method", Jurnal Kemanusiaan, (9), 1-6. 